\title{
Ethnobotany and Language Revitalisation: The Case of Plants in Isubu of Cameroon
}

\author{
Sirih-Nagang Nancy Nyindem \\ Department of Linguistics and African Languages, University of Bamenda, PO box 39, North West region, \\ Cameroon
}

\begin{abstract}
This paper presents the outcome of ethnobotanical documentary research conducted among the Isubu community of the South West Region of Cameroon. Due to destruction of the ecosystem and biodiversity and the fact that the language has been identified as endangered (Atindogbé 2010, Akum 2013), there is a need to conserve indigenous knowledge on plants in this language. The study adopted an ethnographic interview survey. Fifteen language consultants were interviewed residing in from the speech community using Cameroon Pidgin English and the data were transcribed and annotated in ELAN. The article comprises four sections. In section one background information on the Bimbia people and language, the ecology of the region, and the research methodology employed in this research will be presented. Section two discusses the Isubu botanical folk taxonomy that is the way the people classify plants. In section three 1 will provide details of medicinal and other uses of a sample of 27 plants but the quantitative analysis will be drawn from a wider corpus of 92 plants. The focus in section four is on the role of such a study to the pressing need to safeguard, and maintain endangered languages and enhance the interrelatedness of language, culture, and biodiversity. We expect that the outcome of this research will benefit the local community and contribution to the preservation and possible revitalisation of the language.
\end{abstract}

Keywords: Ethnobotany, Revitalisation, Endangered language, Preservation

DOI: $10.7176 /$ JLLL/62-05

Publication date: November $30^{\text {th }} 2019$

\section{Introduction}

Isubu is one of the coastal tribes known as the Sawas and found in the coastal area at the foot of Mt. Fako of Cameroon (tallest Mt. in West Africa). Isubu is a Narrow Bantu language of the Duala group (A231) spoken in the South West Region, Fako Division, Tiko Subdivision, (Eberhard, Simons, and Fennig (2019). It is a Sawa Bantu language alongside Mokpe, Wovea, and Womboko. Alternate names for Isubu are Bimbia, Isubu, Isuwu, $\mathrm{Su}$, Isu, and Subu. It has been identified as an endangered Bantu language of zone A (Atindogbé 2010). They live along the shores and creeks of the sea and their main occupation was fishing and currently engaged in farming. The data exploited in this study were collected in the Bimbia village situated in the Bimbia estuary area east of Limbe. We worked with fifteen language consultants; five men and ten women, with an average age of $63.5 \%$ whilst information were mostly provided by adult women, mainly mothers, because they mostly knew the plants better than the men and the youths.

An ethnobotany approach was adopted in this study because of the importance of carrying out ethnobotanical documentation among indigenous peoples to capture, preserve and revitalize the rapid vanishing ethnobotanical knowledge. Ethnobotanical knowledge is a cultural heritage, a source of cultural pride and culturally relevant learning materials for the indigenous communities that need to be protected (Suminguit 2007). This approach documents the varying usage of plants, for instance, which plants are used for medicinal purposes; the conditions each plant is used to treat, and the manner in which it is prepared and used for other purposes such as food, tools for living and for traditional rites.

Setting out for this research the main target was to get in contact and work closely with native traditional specialists/healers within the community which we believed would have the appropriate information about plants. But was a little disappointed with not able to find one, and was clearly informed the village no longer has a traditional healer/specialist. This gap activates an open eye to the continuous transmission of folk knowledge of plants in this community, coupled with the fact that the lack of inter-generational transfer of the language was identified as one of the factors contributing to the endangered state of the language. Faced with this reality we wondered whether we would get data on the medicinal and other uses of plants in Isubu. However, these doubts were cleared off when we interacted and found some elderly persons who still had some knowledge though limited to the usage of plants within the community. Consequently, the absence of traditional healers in Bimbia has increased the accessibility to modern medicine even though the village has a poor access network to the city and does not have a modern health facility. For this reason, we feel it is accurate to describe the Isubu terminology for plant species, together with the system of medicinal knowledge and other uses which it supports, as a threatened domain of language use.

Data was collected, through semi-structured interviews and participant observations. We interviewed and 
interacted with 15 language consultants; 10 females, 5 males of age 45 to 83 . With the use of a picture guide list of plants found in the region we directly asked questions about the kinds of plant species they know, how and what it is used for, which parts are used and which methods of preparation were employed. For the participant observation component, we collected data by moving to the bushes, forest and the surroundings with the informants in their agricultural activities or participated in the preparation of family meals and recorded information on plant usages whenever it was mentioned by the informant as medicine. Also, participant observations were used to identify in the fields the plant species cited by the informants during interviews. In summary, the data consist of information collected among 15 informants during direct inquiries and in more informal settings where other people could have been present. After the field-trips, the plant species identified by the informants were described, provided the common names and indigenous names. We conducted the researchbacked by a written authorization from the State administrator (SDO-Senior Divisional Officer), the Head of the local community (chief) and the general acceptance of the community.

\section{Isubu ethnobotanical taxonomy}

Every speech community has its own 'ethnobotanical taxonomy', that is, the way in which speakers of a language classify plants, and so it was necessary to identify the ethnobotanical taxonomy used by the Isubu speaking community. The classification of plants is the method of ordering plants on the basis of the features they share in common and this process includes identification and naming of the organisms (Berlin 1992). The importance of classifying plants is that it establishes them as individual units in the living world. In describing the local taxonomy of the Isubu people we drew inspiration from Linnaeus' 19th -century method of classifying plants into different classis taking into account the structural similarities of the organisms, not intended to represent natural groups but only for use in identification. We observed that the local taxonomy of the people is based on the morphological structure of the plants, such as leaf/vegetable plants, trees, grass, etc.

Classis 1- leafy/vegetables

Classis 2- trees

Classis 3-grass

Classis 4- grains

Classis 5- tuber products

The importance of adopting Linnaen's taxonomy is that it can be used to organize the different kinds of living organisms simply and practically. In doing so each species is given a unique name, as compared with common names that are often neither unique nor consistent from place to place and language to language. Thus, in Isubu the nomenclatural features in the formation of plant names of differing degrees of specificity appeared to be highly regular and essentially identical. Below are examples of plants that belong to the various classes adopted from Linnaeus.

\subsection{Plants identified as leafy/ vegetables \\ Classis 1: leafy/Vegetables \\ Names in Isu Common names \\ Béjálíti "tea" \\ ßèjálí ßé ǹdòlè "bitter leafs" \\ ßèjálí lîф \\ ßèjálí lîфćnè ndókó "celery"}

In this class, plants are described as leafy or vegetables because it is mostly the leaves that are used for a particular purpose. For instance, ßèjálí ßé ìdòlè 'bitter leaf' is identified as leaves used in the preparation of ndole (a type of food dish) and Bèjálí lî́ćnè ndókó and Bèjálí lî́ćnè ndókó for parsley and celery respectively as leaves used in the preparation of soup. They do not have a peculiar name and only refer to as leaves for a particular purpose as compared to others which have typical indigenous names.

\section{2: Plants identified as tree}

\section{Classis 2: trees}

Names in Isu

líjà

lìsá

Common names

"palm tree"

"chewing stick"

lìsá "rubber tree"

mwóngè "movingui"

mwèngè "hardwood, african Padauk"

Bèkónyá "sapelle"

ßèkónyá "eucalyptus"

Most of the plants classified in this class grow in the forest, bushes and are very huge in height. They are of 
great importance to the Bimbia people given that they are used in the construction of fishing boats, canoes, paddles, furniture, etc. The majority of these plants are classified as nouns of class 5 and 7 .

\section{3: Names of plants identified as grass}

\section{Classis 3: Grass}

Names in Isu common names

bòwá "green"

bòwá "eru"

bòwá "huckleberry" country dłàmàdłámá"

bòwá "cabbage"

bòwá "lettuce"

Most of these plants in this class are not peculiar to the indigenous environment. They are mostly cultivated elsewhere and purchased from the markets or brought in from far away from bushes. As a result, it is regarded as foreign and named bòwá meaning grass like other plants that grow around, without any particular identification and cultural value.

\section{4: plants identified as grains}

\section{Classis 4: grains}

Names in Isu

mbàsì

kòndì

\section{common names}

koфí "coffee"

ndóndá "garlic"

bíndzi "pea/beans"

ggòndó "groundnuts"

The names of the plants in this class are culturally bound. They are clearly identified within this community and are locally named and classified as nouns of class 9 . This classification is done taking into account their morphology composition.

\section{5: Plants identified as tuber products}

Classis 5: tuber products

Names in Isu

common names

likàwò "cocoyams"

lidzàngá "pineapple"

likpàmbà "cassava"

lìwòkí "pumpkin"

èwá já málíwá "water yam"

ßékpângú "sweet potato"

The folk taxonomy of plants in this class is culturally bound reflecting the peculiarity of the people. They are locally identified and given names taking into account their morphological structures and are classified as nouns of classes $5 \& 7$. 


\section{3: Plants and noun class classification}

Table 1: The Noun class gender of plant names in Isubu

\begin{tabular}{|c|c|c|c|c|}
\hline No. & Sg Plant names & Pl forms & common names & Class gender \\
\hline 1 & 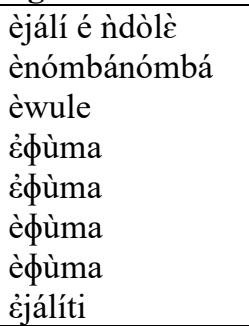 & 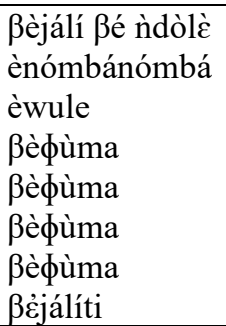 & $\begin{array}{l}\text { "bitterleaf" } \\
\text { "basil" } \\
\text { "banana" } \\
\text { "tomatoes" } \\
\text { "passion fruit" "adam fruit" } \\
\text { "garden egg" } \\
\text { "apple" } \\
\text { "tea" }\end{array}$ & $\begin{array}{l}7 / 8 \\
\text { è -/ } \beta \text { è- }\end{array}$ \\
\hline 2 & $\begin{array}{l}\text { mókòkó } \\
\text { mòdwándwání }\end{array}$ & $\begin{array}{l}\text { mèkòkó } \\
\text { mòdwándwání }\end{array}$ & $\begin{array}{l}\text { "sugar cane } \\
\text { "monkey sugar cane, bush sugar cane" }\end{array}$ & $\begin{array}{l}3 . / 4 \\
\text { mò-/mè- }\end{array}$ \\
\hline 3 & $\begin{array}{l}\text { lilándzò } \\
\text { ìsáì } \\
\text { likkpàmbà } \\
\text { lìdzòkè }\end{array}$ & $\begin{array}{l}\text { màlándłò } \\
\text { màsà } \\
\text { màkpàmbà } \\
\text { màdzòkè }\end{array}$ & $\begin{array}{l}\text { "orange" } \\
\text { "chewing stick" } \\
\text { "cassava" } \\
\text { "eucalyptus" }\end{array}$ & $\begin{array}{l}5 / 6 \\
\text { li-/ mà- }\end{array}$ \\
\hline 4 & 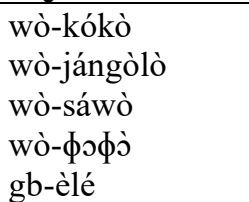 & $\begin{array}{l}\text { mà-kókò } \\
\text { mà-jángòlò } \\
\text { mà-sáwò } \\
\text { mà- } \phi \text { oj̀ } \\
\text { màèlé }\end{array}$ & $\begin{array}{l}\text { "cocoa tree" } \\
\text { "mango tree" } \\
\text { "plum tree" } \\
\text { "pawpaw tree" } \\
\text { "tree, medicine" }\end{array}$ & $\begin{array}{l}\text { 14/6a } \\
\text { wò-/mà }\end{array}$ \\
\hline
\end{tabular}

Table 1 presents the plants and their noun class gender system. Plants in general in Isubu are classified in the noun class gender $7 / 8,3 / 4,5 / 6$, and14/6a where they obtain their singular and plural forms respectively. As such the semantic criteria will be difficult in classifying nouns in the language, however further research needs to throw more light on this assertion.

\section{Uses of selected plants}

This article is just a section of extensive documentary research on phytonyms in two coastal Bantu A endangered languages, thus due to limitation of space only a few of these plants examined in the work will be described below. In relation to a choice, we preferred plants peculiar to the area. However, our analyses will be based on the folk knowledge on 92 plant spices in the language.

1. Ageratum conyzoides (èwòládàkó), common name: king grass

The leaves are harvested and smashed to extract liquid dropped into the nostrils of the patient suffering from headaches. Alternatively, the leaves of èwòlábàkó are wrapped in plantain leaves, put in hot wood-ash and allowed to get steam. It is then smashed and the liquid dropped in the nostrils. In cases of severe headache, the heated leaves are used to massage the forehead of the patient and the fresh leaves are smashed and inhaled. Furthermore, the leaves and roots of èwòlá $\grave{a} k$ ó boiled for about 30 minutes and the liquid served as enema/laxative as a treatment for skin rash locally called ndzetíndzetí (found on the bodies of young babies). It can also be administered as enema without boiling, the liquid from the smashed leaves is administered as a treatment to ease movement in children, experiencing complications in normal growth. The smashed leaves are also used as iodine on fresh wounds to stop bleeding and another leaf placed on it to avoid infection before rushed to the hospital for proper treatment.

2. Annanas comosus (dzàngá) common name: pineapple

dsaingá is an edible fruit. the peelings of the pineapple and even the pineapple itself, with some plants such as fever grass/lemongrass, the bark of a mango tree, plum and guava leaves are boiled together and the concoction drunk as a treatment for malaria fever. It is also used in making fruit juice

3. Aframomum melgueta (ndóngó mǔndá) common name: alligator pepper

Few seeds of ndóngó mǔndá are chewed and swallowed with warm water to heat up the lungs and relieve the individual from cough. It is advisable not to consume it during pregnancy because it could lead to abortion.

4. Aloe vera (aloe vera) common name: aloe vera

Few leaves of aloe vera are washed and the outer layer neatly peeled off to expose the inner layer which produces a slimy liquid. This liquid is extracted and drunk as a treatment for stomachache or stomach disorder, and also used as an antidote for food poisoning or any deadly poisons.

5. Bidens pilosa (ndondskàßàtúwéli "injection for the poor") common name: blackjack, devil's needles

The leaves of the plant are used as a blood booster. For someone suffering from blood shortage, the leaves are boiled and the liquid drunk three times daily.

6. Bryophyllum pinnatum (èlíwàlíwà) common name: never die

The leaves of èßèjálíwà are heated over the fire, smashed with the hands and two drops of the fluid from the 
smashed leaves dropped into the ears morning, afternoon and evening as a treatment for pains inside the ear. In some situations, this fluid is accompanied by kernel oil commonly called mànyàngà. The fluid needs to be administered warm into the ear in order to be effective.

7. Cocos nucifera ( $g$ be ìbànga mó likàwò) "coconut tree"

gbê ìbànga mó likàwò produces edible fruits called ṁbànga mó likà̀ò and the roots are used as medicine for toothache. The roots are boiled for an hour and the liquid administered to the patient to gaggle in the mouth for about 20 minutes. This action is done twice daily: in the morning and in the evening until the pain subsides. The fruit is also used to extract oil which is used in cooking and as a body oil.

8. Carica papaya L. ( $\phi \grave{\partial} \phi \dot{)}$ ) common name: pawpaw

$\phi \grave{\partial} \phi \dot{\prime}$ is used as the name of a plant and a fruit (edible). The dry leaves of $\phi \dot{\partial} \phi \dot{\partial}$ are harvested, washed and boiled together with pineapple peelings and fever/lemongrass for over an hour, and the concoction drunk as treatment fever. Also, the seeds are chewed and swallowed with a glass of water as a treatment for intestinal worms.

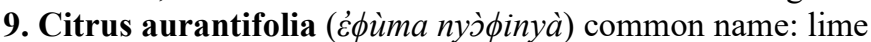

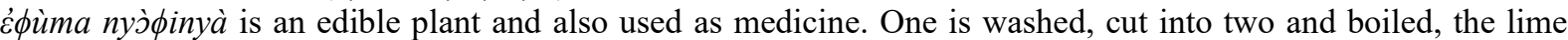
liquid served in a glass and drunk in the mornings and evenings to decongest the chest. Also, the juice squeezed out from it is added in a bucket or bowl of bathing water and used as a treatment for body or foot odour.

10. Cymbopogon (lìmàsèkù/màsèkù) common name: fever grass, lemongrass

lìmàsèkù/màsèkù acquired the common name fever grass because the villagers identified it as the master home remedy for treating colds, fevers (especially malaria) and menstrual cramps. The leaves are boiled and the liquid drunk while hot. It is also drunk cold as a muscle toner and to improve on the skin by reducing pimples.

11. Distemonantus benthamianus (mángè) common name: movingui

mángè is used in making fishing boats, furniture in homes and as firewood. The bark of the tree is ground and used for an enema with children and believed it makes them grow stronger and smarter.

12. Emilia coccinae (lítólámbgà) common name: rabbit grass

The leaves of litólámbgà are washed and eaten raw by the individual as a treatment for stomach disorder and gastritis.

13. Eremomastax speciosa (mbúsà íbă) common name: green and red, two-sided leaf

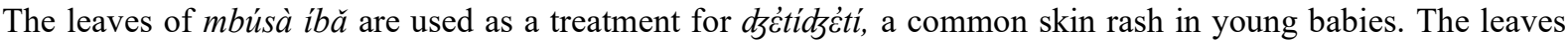
are smashed and the liquid mixed with kernel oil (màjàygà) is used as a body lotion or rubbing oil. The fresh leaves are heated over the fire and smashed, the extracted liquid served in a teaspoon. This is to ensure that the treatment works both inside the stomach and on the body. The liquid can also be served as an enema to the child. Also as a treatment for heat-rash and measles, the liquid extracted from smashed leaves is mixed with ground kalaba-chalk (a brownish-white, edible chalky substance) and applied on the body.

14. Manihot esculenta Grantz (likpàmbà) common name: cassava

Both the bunch of tuber-type roots of likpàmbà and its leaves are both edible. The leaves are also used as antipoison medicine. the young fresh leaves of the cassava plant are washed, smashed and the liquid squeezed into a glass and drunk by the individual to neutralise the poison. The cassava tuber is used to fabricate starch used for the treatment of clothes during laundry.

15. Mimosa pudica (ènàygídź́) common name: touch me not

The leaves of ènàygídz’́ are smashed mixed with water and administer as an enema as a treatment for scabies and as an internal cleansing agent.

16. Musa sapientum (mèké) common name: plantain

The stem of mèk $\dot{\varepsilon}$ is used during local child delivery. The pregnant woman sits on a small plantain sucker placed on leaves in order to lift up her body from the floor, during delivery. This is to ensure that the baby together with its placenta can be carefully received on the plantain leaves.

The sucker is also used to bury the navel or dried cord of the newborn baby. Traditionally, the umbilical cord is buried together with a plantain sucker or coconut seedling. It is believed that as the plantain sucker or coconut seedling grows to maturity and bears fruits so too will the child grows to maturity. Consequently, when the child grows to adulthood he/she is shown the plant which the child now owns. It symbolises life. The liquid from the stem functions as a natural glue. It is mostly used on corpses to shut the eyes or the mouths. The young bunch seed / kpéjàlikj/ symbolizes a child and use when burying women who die during childbirth leaving behind the child. The young seed is harvested and placed in the arms of the deceased in a comfortable position like a mother nursing her baby. It is believed that if this is not done the dead mother can feel very lonely without the child and may come back for her baby which would lead to the death of the baby immediately after the burial of the mother. The leaves of the plantain are used as medicine to cure night fire. They are boiled and the liquid drunk and administered as an enema. Also, the plantain fruit is edible and widely consumed within the community.

17. Nicotiana tabacum (tâkò) common name: tobacco

Bèjálí Bétâkò "tobacco leaves" are used for medicinal purposes as a treatment for headaches, hiccough and to stop bleeding. As treatment for headaches, the dried leaves are ground to dust and sniffed through the nostrils, 
for hiccough the dried leaves are soaked in water for some time in order to extract its tobacco content and the liquid drunk and to arrest bleeding the fresh leaves are ground into a paste and applied on the fresh wound.

18. Ocimum gratissimum L. Forsk (más̀̀ ò) common name: másว̀pò

The ethanolic extract of the leaves of másà $\dot{o}$ is used in traditional medicine as a treatment of several ailments such as wounds, skin and gastrointestinal infections, etc. The parts of the plant used are the leaves and the stems. the leaves together with other different types of fruits, tree leaves (such as mango, orange or pawpaw) are boiled in a big pot with water and administered differently as a treatment for malaria. Firstly, the patient undresses, sits on a small stool in front of the hot pot containing the concoction and is covered with a blanket in order to inhale the hot vapour and aroma, and sweats out the fever. After which he drinks a glass of the concoction either cold or hot three times daily.

Furthermore, as a treatment for stomach ache the leaves are boiled and drunk as tea. As treatment for nose bleeding, the leaves are warmed over the fire, squeezed and the extract dropped into the nostrils.

Also, as medicine for headache, the leaves are smashed in between the palms for some seconds and the aroma inhaled. And as a laxative, the leaves are harvested, washed, smashed and warm water poured into the content and used for enema. The stems of másə̀pò are used as toothbrushes and the aroma suppresses mouth odour. Traditionally this plant is said to have supernatural powers and is believed to be particularly effective in sending away evil spirits.

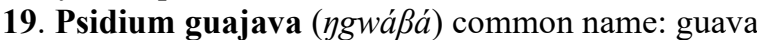

ygwá $\beta a ́$ produces an edible fruit and the stem is used as firewood for home cooking. The young leaves are harvested, washed and chewed as a treatment for stomach aches and dysentery. The young stems are used as chewing sticks (toothbrush) for their good taste and ability to remove mouth odours.

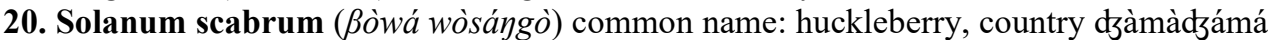

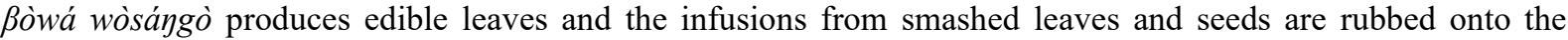
gums of children who have developed crooked teeth. Also, the smashed seeds are used as a dye for the slates of school pupils.

21. Saccharum officinarum (mókòkó) common name: sugar cane mókòkó is edible and also used as a treatment for waist pain. The leaves, known as "tátúwè", of the species that itches are boiled and taken as an enema to relieve waist pain.

22. Senna alata (ènàygídzó) common name: ringworm bush "craw-craw"

The leaves of ènàygídz’́ are used as medicine for skin rash. They are smashed and rubbed on the affected area of the body. The leaves are also used for the enema to clean the stomach and it is squeezed and the liquid drunk as a treatment for internal stomach fungi.

23. Spilanthes filicaulis (lísj̀ lákómbé) common name: cock’s eye

The stem of lís̀ lákómbé is used to treat toothache. It is ground together with alligator pepper, until it forms a paste, and applied to the aching tooth. Also as treatment of palpitation in the child "liwế" the leaf is ground together with nine grains of alligator pepper and a spoonful of the mixture administered preferably at $4 \mathrm{pm}$ when it sunsets.

24. Talinum fruticosum (bذ̀l’̀bí) common name: waterleaf

bj̀ljbi is an edible plant and the leaves are smashed along with water and administered as an enema as a treatment for measles and as a laxative.

25. Telferia occidentale (ékj̀yóbón) common name: fluted pumpkin

ékj̀ý́bón is an edible vegetable and the leaves are used as a medication for blood shortage and as antibiotics. Liquid from squeezed leaves of two or three bundles of ékj̀ýmbón is mixed with two tins of peak milk and a bottle of Guinness and drunk. This concoction increases the blood level and provides strength against any form of sickness. Also, as a treatment for typhoid fever, the liquid from the squeezed leaves is served in a glass and drunk morning and evening.

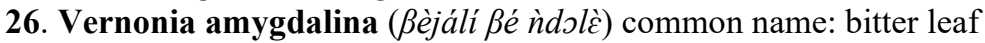

This plant is edible and the leaves used for varied purposes. The young leaves of ßèjálí $\beta$ éǹdòlè are smashed into a paste and applied on fresh wounds to arrest bleeding before the patient is rushed to the hospital. Also, the leaves are washed and smashed with some quantity of water, and the bitter liquid drunk as a treatment for diabetes and stomach pains.

27. Zingiber officinale (dzindzà) common name: ginger

dzindzà is steeped in boiling water to make ginger tea, and drunk as a tea with honey. It is also used to make candy or ginger drink. Tea brewed from ginger is a common folk remedy for colds and cough (consumed with honey).

A summary statistics of the different uses of plants as medicine, food, tools and in performing traditional rites in Isubu are provided on the table below. 
Table 2: Plants and major uses in Isubu

\begin{tabular}{|c|c|c|c|c|c|}
\hline SN & Common names & Medicine & Food & Tool/products & Tradition \\
\hline & & Isu. & Isu & Isu. & Isu. \\
\hline 1. & mango fruit & yes & yes & yes & No \\
\hline 2. & soursop & yes & yes & yes & No \\
\hline 3. & nutmeg & No & yes & yes & No \\
\hline 4. & oyang & No & yes & No & No \\
\hline 5. & parsley & yes & yes & No & No \\
\hline 6. & celery & yes & yes & No & No \\
\hline 7. & carrot & yes & yes & No & No \\
\hline 8. & cocoyams & yes & No & No & No \\
\hline 9. & palm tree & yes & yes & yes & yes \\
\hline 10. & coconut & yes & yes & yes & No \\
\hline 11. & king grass & yes & No & No & No \\
\hline 12. & blackjack, devil's needles & yes & yes & No & No \\
\hline 13. & rabbit grass & yes & yes & No & No \\
\hline 14. & sunflower & yes & No & yes & No \\
\hline 15. & bitter leaf & yes & yes & No & No \\
\hline 16. & lettuce & yes & yes & No & No \\
\hline 17. & cabbage & yes & yes & No & No \\
\hline 18. & tomato & yes & yes & No & No \\
\hline 19. & huckleberry/countrydłàmàdzámá & yes & yes & yes & No \\
\hline 20. & waterleaf & Yes & yes & No & No \\
\hline 21. & pineapple & yes & yes & No & No \\
\hline 22. & pawpaw & yes & yes & No & No \\
\hline 23. & watermelon & yes & yes & No & No \\
\hline 24. & apple & yes & yes & No & No \\
\hline 25. & orange & yes & yes & No & No \\
\hline 26. & lime & yes & yes & No & No \\
\hline 27. & bitter cola & yes & yes & No & yes \\
\hline 28. & chewing stick & yes & No & yes & No \\
\hline 29. & sweet potato & yes & yes & No & No \\
\hline 30. & green pepper, bell green & No & yes & No & No \\
\hline 31. & black/white pepper & No & yes & No & No \\
\hline 32. & bush pepper & yes & yes & No & No \\
\hline 33. & alligator pepper & yes & yes & No & yes \\
\hline 34. & sugar cane & yes & yes & No & No \\
\hline 35. & monkey sugar cane/bush sugar cane & yes & yes & No & No \\
\hline 36. & never die & yes & yes & No & No \\
\hline 37. & pumpkin, & yes & yes & No & No \\
\hline 38. & fluted pumpkin & yes & yes & No & No \\
\hline 39. & egusi & yes & yes & No & No \\
\hline 40. & ndzansang & yes & yes & No & No \\
\hline 41. & water yam & - & yes & No & No \\
\hline 42. & rubber & yes & yes & yes & No \\
\hline 43. & cassava & yes & yes & yes & No \\
\hline 44. & touch me not, & yes & No & No & No \\
\hline 45. & green Beans & yes & yes & No & No \\
\hline 46. & soya beans & yes & yes & No & No \\
\hline 47. & ringworm bush "craw-craw" & yes & No & yes & No \\
\hline 48. & four corners & yes & yes & No & No \\
\hline 49. & groundnuts & yes & yes & yes & No \\
\hline 50. & pea & yes & yes & No & No \\
\hline 51. & eru & yes & yes & No & No \\
\hline 52. & african mango/ bush mango & yes & yes & yes & No \\
\hline 53. & basil, & yes & yes & No & No \\
\hline
\end{tabular}




\begin{tabular}{|c|c|c|c|c|c|}
\hline SN & Common names & Medicine & Food & Tool/products & Tradition \\
\hline 54. & másว̀pò & yes & yes & No & No \\
\hline 55. & fever Grass, lemongrass & yes & yes & No & yes \\
\hline 56. & avocado pear & yes & yes & yes & No \\
\hline 57. & guava & yes & yes & yes & No \\
\hline 58. & passion fruit/ adam fruit & yes & yes & yes & No \\
\hline 59. & aloe vera & yes & yes & No & No \\
\hline 60. & brazil bress, para cress & yes & yes & No & No \\
\hline 61. & green and red/two-sided leaf & yes & yes & No & No \\
\hline 62. & green & yes & yes & No & No \\
\hline 63. & confrey & yes & yes & No & No \\
\hline 64. & garlic & yes & yes & No & No \\
\hline 65. & onion & yes & yes & No & No \\
\hline 66. & okro & yes & yes & No & No \\
\hline 67. & kreng kreng & yes & yes & No & No \\
\hline 68. & cocoa & yes & yes & yes & No \\
\hline 69. & cotton & yes & No & No & No \\
\hline 70. & kola nut & No & yes & No & No \\
\hline 71. & jack fruit & No & yes & No & No \\
\hline 72. & plantain & yes & yes & yes & yes \\
\hline 73. & banana & yes & yes & yes & No \\
\hline 74. & movingui & yes & No & yes & No \\
\hline 75. & hardwood, African Padauk & No & No & yes & yes \\
\hline 76. & sapelle & No & No & yes & No \\
\hline 77. & mahogany & No & No & yes & No \\
\hline 78. & eucalyptus & yes & No & yes & No \\
\hline 79. & ironwood & No & No & yes & yes \\
\hline 80 . & bilinga & No & No & yes & No \\
\hline 81. & cactus & No & No & No & yes \\
\hline 82. & elephant grass & No & yes & yes & No \\
\hline 83. & maize & No & yes & yes & No \\
\hline 84. & rice & No & yes & yes & No \\
\hline 85. & coffee & No & yes & No & No \\
\hline 86. & arish potatoes & No & yes & No & No \\
\hline 87. & garden egg & No & yes & No & No \\
\hline 88. & country onion & yes & yes & - & No \\
\hline 89. & ginger & yes & yes & yes & - \\
\hline 90. & tea & yes & yes & - & - \\
\hline 91. & tobacco & yes & yes & - & - \\
\hline \multirow[t]{2}{*}{92.} & bahama grass; dog's tooth grass & yes & - & - & - \\
\hline & Total of yeses only & 73 & 76 & 30 & 08 \\
\hline
\end{tabular}

The data reflected in table 2 indicate the number of different usages of the plants examined in this research. The majority of them are used for more than one purpose within the communities. These statistics are used to arrive at the various percentages of usage for the different plants in the language as reflected on the chat below. 
Chat 1: Percentages of the various usages of plants in Isubu

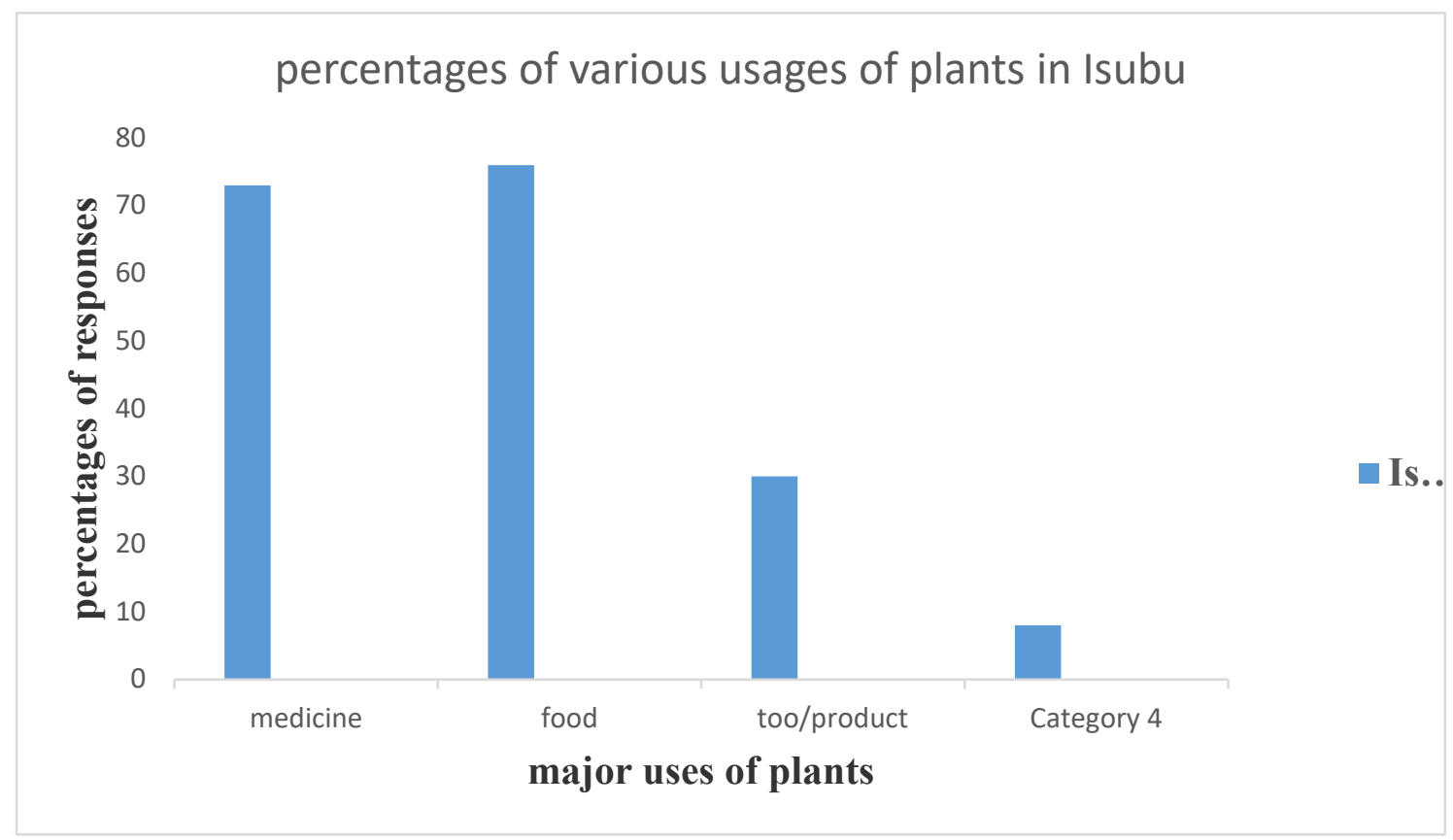

Researching on ninety-two plant species describing their folk and cultural importance, we observe that plants are mostly used for food scoring the percentage of 40.6 , followed closely by plants used for medicinal purposes scoring $39.0 \%$, for manufacturing tools, register $16 \%$ and used for traditional purposes scoring $4.3 \%$. The Isubu people use plants mostly for food and medicinal purposes thus; this indicates how much they rely on their local ecology for sustainable living.

\section{The significance of the ethnobotany to language revitalisation.}

Given the endangered state of Isubu, it is obvious that knowledge in many domains of language use is under threat including biodiversity. The previous sections have described the local taxonomy, the folk knowledge and uses of a sample of plant spices in Isubu. In the medicinal domain due to the absence of traditional specialists/healers, this knowledge is not widely spread within the community but upheld by just a few (mostly women). However, few Isubu inhabitants uphold some ethnobotanical knowledge with the proportion of fewer men than women. For example; the men know the trees suitable for the manufacturing of their fishing boats, canoes, paddles, nets, etc. with some whose local names cannot be remembered while the women, on the other hand, portray a wider ethnobotanical knowledge as they use plants as a major spice in their daily cuisine and as first aid medicine in their homes.

The ethnobotanical knowledge of plants in this community is threatened in varying ways. Firstly; the absence of traditional healers and a modern health facility within the community has hastened the quest for modern health facilities in the neighbouring city. Also soliciting help from traditional healers from neighbouring villages may cause people to lose interest in traditional medicine and thereby reduces the motivation for ethnobotanical knowledge to be passed on to the younger generation. Secondly, the preservation of ethnobotanical knowledge and terminology of fauna in Isubu is threatened given that this local knowledge can only be transmitted orally and the fact that one of the major reasons for the endangered situation of the language is the gap of the intergenerational transfer. There is the risk that this knowledge cannot be passed on to the future generation if the language is not used as a medium of transmission. This further expresses the negative attitude expressed by the youths towards their language who comfortable identify themselves with English and CPE and unfortunately their mother tongue is a vessel for this knowledge and practices. Also, the fact that in the educational sector these children are not exposed to the mother tongue as a language of instruction or subject at the initial stage of schooling makes them consider their language as intellectually inferior and so the fundamental knowledge and practices inherent. This research would like to propose some actions in which the documentation of folk ethnobotanical knowledge can help to resist these threats on the Isubu ethnobotanical knowledge and terminology.

Isubu is an endangered language and with the assertion that the loss of one's language is to lose one's identity as language is a carrier of a people's culture which is a learned system of shared beliefs and feelings passed on from one generation to the next. So the folk knowledge of plants is obviously endangered as well, hence it is vital to conserve the language and the culture along with its biological ecosystems in order that this 
knowledge is preserved. The preservation of Isubu, therefore, is a major step to enhancing and preserving ethnobotanical knowledge in the language. This preservation should be upheld by different stakeholders such as the government, local and researchers. In the domain of the medicinal use of plants, although awareness of traditional medicine is gradually gaining interest in Cameroon with the government passing the bill authorising the operation of herbal clinics and acknowledging traditional medicinal practitioners, more sensitizing still needs to be done in the national languages over the medial in order to build and re-enforce the confidence of the people on the importance of such health facilities to improve on the health situation of the nation.

Furthermore, to fall in line with others (Batibo 2001, Nicolle 2004) the documentation of traditional ethnobotanical knowledge can contribute to language maintenance by providing an impetus to mother tongue education as advocated by UNESCO as one of the millennium development Goals (MDGs). Thus Isubu should be used as the language of instruction at the elementary and basic levels of education and indigenous knowledge as the basis for teaching hygiene and many other school subjects. As stated by Batibo (2001:320) developing a curriculum out of the community's experience will give the language a newer and brighter future. Of course, this can only be achieved if there is available documented data of the folk knowledge (Nyindem 2018).

In addition, a school curriculum on mother tongue can only be visible with the availability of teachers adequately trained in mother tongue education and relevant teaching material provided. This research is an outcome of multidisciplinary documentary research which has amongst many of its achievements a bilingual dictionary from Isubu to English and English to Isubu. It has also provided primers in the language to be used in schools. At the level of the government, even though Art 3, paragraph 2 of section 1 of the Cameroonian constitution indicates the promotion of local language and culture and the Minister of higher education then encourages and recommends the creation of University departments for Cameroonian languages, we strongly think the ignition point and procedure are misplaced. It is supposed to be introduced at the basic and elementary levels of the educational ladder, not vice versa as done which accounts for why its implementation is not yet felt and appreciated by the people. Consequently, this could pose as one of the reasons which fan the negative attitude expressed towards the incorporation of mother tongue in the educational system in Cameroon.

Lastly, at the level of the speech community, a language committee should be put in place with roles clearly defined. It should have as one of its major priorities to encourage the natives, especially the children, to speak Isubu and identify themselves with it. For instance, games and competitions should be organised for the best poetry, song or story with rules stated in Isubu and awards provided for the winners or best performance s. This will act as a motivation factor to the youths to develop a positive attitude, use and understand the language thereby enhancing its vitality.

\section{Conclusion}

The vitality of a language can only be successfully enhanced beginning with a positive attitude expressed by the speakers of the language. The negative attitude expressed by the Isubu youths is not admired by the adults who are sad and willing to remedy the situation and offer collaboration to any attempt to safeguard their linguistic patrimony. Also, the government's role in ensuring a visible and effective curriculum for mother tongue education will be of much value.

\section{References}

Akum, P. T. J. (2011). Isubu as an endangered language. "The University of Buea, Unpublished MA thesis.

Alves, R. R. N. (2012). Relationships between fauna and people and the role of ethnozoology in animal conservation. Ethnobiology and Conservation, 1(2): 1-69. Doi:10.15451/ec2012-8-1.2-1-69.

Alves, R.R.N., Wedson, M.S. (2011). Ethnozoology in Brazil: Current status and perspectives. Journal of Ethnobiology and Ethnomedicine, 7(22): 7-22. Doi: 10.1186/1746-4269-7-22.

Atindogbé, G., Nyindem, N. \& Kemmermann, D. (2013). Isubu dictionary. Cologne: Institute for African Studies: University of Cologne.

Balick, M. J. \& Cox. P. A. (1996). Plants, people, and culture: The science of ethnobotany. New York: Scientific American Library, HPHLP.

Batibo, H. M. (2001). The endangered languages of Africa: a case study from Botswana. In: L. Maffi (ed.). On biocultural diversity. Linking language, knowledge, and the environment. Pp. 311-24. Washington and London: Smithsonian Institution Press.

Berlin, B. (1992). Ethno biological classification: Principles of categorization of plants and animals in traditional societies. New Jersey: Princeton University Press.

Coelho, G. (2005). Language documentation and ecology: Areas of interaction. In P. Austin(ed.), Language documentation and description: 3, 63-74.

Cotton, C. M. (1996). Ethnobotany: Principles and application. London: Wiley. Retrieved from: http://purl.oclc.org/estimates Crapo, R. H. 2002. Cultural anthropology: Understanding ourselves and others (5th ed.). New York: Mc Graw-Hill Companies. 
Cunningham, T. (2000). Applied ethnobotany: people, wild plant use and conservation. London: Earthscan.

Harrison, K. D. (2001). Losing species, losing languages: Connection between biological and linguistic diversity. Southwest Journal of linguistics. 15, 89-108.

Heine, B. \& Legère K. (1995). Swahili Plants: An ethnobotanical survey. Cologne: Rüdiger Köppe.

Maffi, L. (1996). Endangered Languages, endangered knowledge, and endangered environments. Position paper for the Berkeley conference. Retrieved http://ucjeps.berkeley.edu/Endangered_Lang.Conf/Endangered_Lang.html.

Maffi, L. (2001). On the interdependence of biological and cultural diversity. In L. Maffi (ed.), On biocultural diversity: Linking Language, Knowledge, and the environment. Washington: Smithsonian Institution Press.

Nicolle, S. (2004). The relevance of ethnobotanical studies to linguistic vitality: The case of plant use and classification among the Digo of Kenya. University of Nairobi Occasional Papers in Language and Linguistics, VL 2:86-103.

Nyindem, S.N.N. (2018) A documentary linguistics study of phytonyms and zoonyms in Isubu and Wovea, two coastal Bantu A languages of Cameroon. University of Buea unpublished PhD dissertation.

Suminguit, V. J. (2007). Ethnobotanical documentation: A user's guide. Retrieved from http://www.accu.or.jp/ich/en/pdf/c2006Expert_SUMINGUIT_2.pdf 